\title{
ANALISIS PEMIKIRAN AR. MOLOU DALAM MEMAJUKAN GELIAT PENDIDIKAN ISLAM DI GORONTALO
}

\author{
Supi'ah ${ }^{1}$, Abdur Rahman Adi Saputera ${ }^{2}$ dan $Z^{2 a h d i}{ }^{3}$ \\ ${ }^{1,2}$ Insititut Agama Islam Negeri (IAIN) Sultan Amai Gorontalo \\ ${ }^{3}$ Kantor Kementerian Agama Provinsi Bengkulu \\ supiahbd@gmail.com
}

\begin{abstract}
Penelitian ini bertujuan menelisik pemikiran AR Molou dalam memajukan geliat pendidikan Islam di Gorontalo. Jenis penelitian ini adalah kualitatif dengan menggunakan pendekatan biografi dan historis, yang diperkuat dengan sumber data primer dan sekunder, Teknik pengumpulan data yang digunakan : 1) Observasi, 2) Wawancara, 3) Dokumentasi. Sedangkan analisis data dilakukan dengan beberapa tahapan: 1) Metode Deskriptif, dan 2) Metode analisis biografi. Adapun hasil penelitian menyatakan bahwa sumbangsih pemikiran beliau dalam memajukan geliat pendidikan Islam di Gorontalo yang paling berpengaruh adalah konsep integrasi antara ilmu dan agama yang telah lama terdikotomi, entah itu diakibatkan oleh eskalasi perpolitikan lokal dan nasional atau bahkan implikasi oleh sisa-sisa doktrin negatif warisan yang ditinggalkan oleh kolonial.
\end{abstract}

Keywords: Pemikiran, AR. Molou, Pendidikan Islam, Gorontalo

\section{Pendahuluan}

Pendidikan merupakan aspek penting bagi perkembangan sumber daya manusia, sebab pendidikan merupakan wahana atau salah satu instrumen yang digunakan bukan saja untuk membebaskan manusia dari keterbelakangan, melainkan juga dari kebodohan dan kemiskinan. Disisi lain, pendidikan dipercayai sebagai wahana perluasan akses dan mobilitas sosial dalam masyarakat baik secara horizontal maupun vertikal. Kemajuan Bangsa Indonesia hanya dapat 
dicapai melalui penataan pendidikan yang baik. Upaya peningkatan mutu pendidikan diharapkan dapat menaikkan harkat dan martabat manusia Indonesia. Pada perkembangan era globalisasi sekarang ini menuntut semua bidang kehidupan untuk menyesuaikan visi, misi, tujuan dan strateginya agar sesuai dengan kebutuhan, dan tidak ketinggalan zaman. Dengan demikian, maka sistem pendidikan nasional senantiasa harus dikembangkan sesuai dengan kebutuhan dan perkembangan yang terjadi baik ditingkat lokal, nasional, maupun global. ${ }^{1}$

Pada hakikatnya, pendidikan memiliki peranan yang sangat besar untuk menciptakan masa depan yang lebih baik bagi setiap pribadi manusia maupun masyarakat dan negara di mana ia berada, ${ }^{2}$ selain itu pendidikan juga adalah suatu usaha dalam meninggalkan warisan nilai positif, sebagai penolong dan penuntun umat manusia dalam menjalani kehidupan dan sekaligus untuk memperbaiki nasib dan peradaban umat manusia. Tanpa pendidikan dapat dipastikan bahwa manusia sekarang tidak berbeda dengan generasi manusia masa lampau. Karena itu, secara ekstrim dapat dikatakan bahwa maju mundur atau baik buruknya peradaban suatu masyarakat atau bangsa sangat ditentukan oleh bagaimana proses pendidikan yang dijalani oleh masyarakat bangsa tersebut. Sebagaimana pendidikan islam yang bertujuan untuk mengembangkan potensi yang dimiliki manusia dan dapat berperilaku baik sesuai dengan kaidah-kaidah islam, menjadikan Al-Qur'an dan Hadits sebagai pedoman dalam menuntun hidup dan mencapai kesempurnaan hidup, semua ini dapat diperoleh melalui pendidikan. Pendidikan yang baik akan mengantarkan manusia menjadi insan kamil dan dapat menjalankan amanah Tuhan dengan baik. Persoalan ini kemudian menjadi sebuah tugas yang menuntut umat untuk harus memiliki pendidikan yang bagus dan baik. berbagai macam usaha dalam rangka perbaikan pendidikan pun terus dilakukan, mulai dari kurikulum, tujuan pendidikan, metode yang harus dipakai pada saat belajar mengajar berlangsung, strategi yang harus digunakan dan lain-lain yang berkenaan dengan pendidikan.

Masyarakat Gorontalo telah mengalami berbagai bentuk sistem pendidikan. Dinamika pendidikan membawa perubahan akibat pengaruh dari berbagai macam persoalan seperti politik kekuasaan dan lain

\footnotetext{
${ }^{1}$ Abdur Rahman Adi Saputera, "Analisis Faktor Penghambat dan Pendukung Implementasi KTSP Di Madrasah Aliyah Alkhairaat Kota Gorontalo," Kariman 07, No. Pendidikan Dan Pemikiran Keislaman (2019): 183-204.

${ }^{2}$ M Rifian Panigoro \& Abdur Rahman Adi Saputera, "Implementasi Metode Sam'iyah Syafahiyah Pada Siswa Sebagai Upaya Meningkatkan Kemampuan Penguasaan Mufradat," A Jamiy: Jurnal Bahasa dan Sastra Arab 9 , no. 2 (2020): 164-178.
}

152 | Kariman, Volume 08, Nomor 02, Desember 2020 
sebagainya. Gorontalo pernah melalui suatu masa yang sangat dinamis, ketika terlibat dalam hubungan lintas teritorial dan interaksi lintas budaya. Pendidikan telah membawa implikasi besar terhadap perubahan sosial budaya masyarakat. Masuknya kekuasaan kolonial membawa perubahan pendidikan dengan sisten pendidikan yang beraneka ragam. Walaupun sistem pendidikan diterapkan pada diskriminasi dengan memandang status sosial, namun bagaimanapun juga pendidikan kolonial memiliki peran penting dalam organisasi pergerakkan di Gorontalo. Masa pendudukan Jepang, sistem pendidikan memiliki arti penting setelah diseragamkannya sistem pendidikan, sehingga sistem diskriminasi melalui status sosial dihapuskan. Faktor ini memberi peluang untuk mendapatkan pendidikan lebih tinggi. Sistem pendidikan mengalami kemajuan pesat setelah dibukanya perguruan tinggi di Gorontalo. Para pelajar yang menamatkan pendidikan sekolah menengah atas mempunyai kesempatan lebih besar untuk melanjutkan pendidikan. Tidak dapat dipungkiri peranan pelajar dan mahasiswa sebagai pelopor pembentukan propinsi Gorontalo. ${ }^{3}$

Ada banyak tokoh pendidikan yang cukup terkenal di Provinsi Gorontalo, seperti Thayyeb Gobel dengan pesantren Hubulo-nya, Hamrain Kau dengan pesantren Al-Falah-nya, Mansoer Pateda dengan sumbangsih pemikirannya yang tertuang dalam wujud buku-bukunya, Nelson Pomalingo yang berhasil mengembangkan Universitas Gorontalo dari IKIP, juga merintis Universitas Muhammadiyah Gorontalo, serta masih banyak lainnya, dan salah satu diantara mereka adalah AR. Molou, beliau adalah tokoh sekaligus figur berpengaruh yang telah banyak melakukan perubahan-perubahan positif terhadap aras pendidikan Islam di Gorontalo. Beliau berhasil mengembangkan konsepsi pendidikan islam yang berhasil terlepas dari kekangan isu dikotomi keilmuaan sebagaimana yang terjadi sebelumnya di Gorontalo, hal ini beliau buktikan dengan mendirikan Yayasan Nuruttaqwa yang membawahi Madrasah Tsanawiyah dan Aliyah berbasis integrasi spiritual dan ilmu pengetahuan modern. Gagasan dan pemikirannya banyak diadopsi dan dikembangkan sebagai contoh ideal

${ }^{3}$ Syamsi Pomalingo, Dkk, Sejarah Pendidikan di Gorontalo, ed. Percetakan BNPB Sulawesi Utara (Manado, 2012). 29

Kariman, Volume 08, Nomor 02, Desember 2020 | 153 
dalam membangun dan menjalankan suatu lembaga pendidikan di Gorontalo. oleh karena jasa-jasanya yang besar, beliau diberikan gelar adat Ta'o Ilomata Ilo Masa yang artinya Putra Indonesia terbaik kelahiran Gorontalo yang mengabdikan dirinya, di bidang Pendidikan dan Kemasyarakatan. Jiwa keihlasan dan keteladanannya selalu menjadi suri tauladan, ketegaran dan kegigihannya banyak menginspirasi kaum guru dan para muridnya. Belakangan beliau termasuk salah satu tokoh yang hampir-hampir terlupakan karena hingga saat ini belum ada yang menuliskan jasa dan pengabdiannya untuk diabadikan, padahal banyak masyarakat terutama dari daerah Limboto yang sangat mengaggumi kegigihannya dalam mendobrak kebodohan-kebodohan pengetahuan melalui pendidikan islam yang banyak berkembang. Tidak dapat dipungkiri bahwa AR. Molou adalah salah satu putra terbaik Gorontalo yang telah banyak membawa perubahan besar terhadap dunia pendidikan di Gorontalo. Konteks penelitian ini di fokuskan pada upaya penulis dalam menelisik biografi, pemikiran dan kontribusi pemikiran AR. Molou dalam membangkitkan gairah memajukan dunia pendidikan di Gorontalo.

\section{Metode Penelitian}

Pada penelitian ini menggunakan jenis penelitian kualitatif. Penelitian kualitatif adalah suatu jenis penelitian yang menghasilkan temuan-temuan yang tidak diperoleh oleh alat-alat prosedur statistik kuantifikasi. Adapun pendekatan yang digunakan adalah pendekatan biografi dan historis, ${ }^{4}$ yang

\footnotetext{
4 Penelitian Biografi merupakan jenis penelitian kualitatif tentang seorang individu dan pengalamannya sebagaimana di katakan kepada peneliti atau ditemukan dalam dokumen-dokumen. Tujun penelitian ini adalah mengungkap pengalaman menarik yang sangat mempengaruhi atau mengubah hidup seseorang. Penulisan biografi berakar pada disiplin-disiplin yang berbeda dan telah mengalami pembaruan. Penulisan biografi ditemukan dalam prespektif sastra, sejarah, antropologis, psikologis, sosiologis, maupun dalam pandangan interdisiplin, sedangkan Sumber data primer dimulai dengan melakukan observasi awal. Sumber data primer adalah data otentik data langsung dari tangan pertama tentang masalah yang diungkapkan, secara sederhana data tersebut disebut data asli, sedangkan Penelitian historis merupakan jenis penelitian kualitatif yang bertujuan merekonstruksi kondisi masa lampau secara objektif, sistematis, dan akurat. Dengan kata lain, penelitian sejarah bertugas mendeskripsikan sebuah gejala, tetapi bukan gejala bukan yang terjadi pada penelitian dilakukan. Melalui penelitian ini, bukti-bukti dikumpulkan, dievaluasi, dianalisis, dan disintesiskan. Selanjutnya, berdasarkan bukti-bukti tersebut dirumuskan kesimpulan. Hasil penelitian sejarah biasanya berupa narasi deskriptif. Dalam penelitian sejarah, terdapat hubungan secara kronologis yang benar-benar utuh antar manusia, peristiwa, waktu, dan tempat. Lihat Imam Gunawan, "Metode Penelitian Kualitatif: Teori dan Praktik," Jakarta: Bumi Aksara, 2014.
} 
diperkuat dengan sumber data primer dan sekunder, ${ }^{5}$ Teknik pengumpulan data yang digunakan peneliti adalah: 1) Observasi, 2) Wawancara, 3) Dokumentasi. ${ }^{6}$ Sedangkan analisis data, peneliti berusaha untuk memberikan uraian yang mendasar pada analisis, menjelaskan pola uraian, dan juga mencari hubungan antara dimensi-dimensi uraian yang dilakukan dengan beberapa tahapan: 1) Metode Deskriptif, dan 2) Metode analisis biografi. $^{7}$

\section{Biografi Singkat AR Molou}

AR Molou lahir pada tanggal 16 juli 1923 di desa Kayu Bulan yang sekarang berkembang menjadi kelurahan Kayu Bulan kecamatan Limboto Kabupaten Gorontalo. Beliau adalah anak kelima dari Bapak Razak Molou yang bekerja sebagai petani dan Ibu Bue Isa sebagai ibu rumah tangga, dan memiliki sembilan bersaudara, yang urutannya yaitu Hawa Molou, Husain Molou, Kadir Molou, Jafar Molou, Abdul Latif Molou, Fatmah Molou, Arif Molou, Abdurahman Molou, dan Yusuf Talomo. AR Molou mempersunting seorang wanita yang bernama Latifah Dangkua tepatnya pada saat beliau berumur 39 tahun pada tahun 1962, saat itu AR Molou masih sementara menjalankan studinya di Kulliyatul Muallimin. Pada saat itu diutus kakaknya oleh orang tuanya untuk mengajak pak AR Molou

\footnotetext{
${ }^{5}$ Sumber data primer yang menjadi pokok penelitian ini yaitu : mengenai perjalanan biografi dari seorang Tokoh Pendidikan Islam di Gorontalo AR. Molou, adapun Sumber data sekunder adalah data yang mengutip dari sumber lain sehingga tidak bersifat otentik karena diperoleh dari sumber kedua atau ketiga. Karena tokoh yang diteliti sudah lama wafat maka peneliti melakukan penelitian melalui data sekunder. Dalam memperoleh data sekunder ini peneliti melakukan wawancara dengan anak dari AR. Molou dan juga kerabat terdekat beliau, serta melakukan observasi mengenai karya monumental beliau yaitu Yayasan MTs dan MA Nuruttaqwa Limboto.

${ }^{6}$ Galang Surya Gumilang, "Metode Penelitian Kualitatif Dalam Bidang Bimbingan Dan Konseling," Jurnal Fokus Konseling 2, no. 2 (2016): 1-20.

${ }^{7}$ Metode Deskriptif, yaitu dimana peneliti menggunakan system penulisan dengan cara mendeskripsikan realitas dan fenomena sebagaimana adanya yang nyatakan dari presepsi subjek. Metode ini menjelaskan apa saja yang menjadi keseharian dan peran dari AR Molou yang patut untuk diungkap. Sedangkan Teknik analisis biografi ini bertujuan untuk menganalisa sejarah kehidupan seseorang. Yang menjadi objek kajiannya orang tersebut dan seluruh pengalaman hidupnya, mulai dari kelahirannya, menjadi dewasa, sampai dengan masa tuanya, bahkan sampai orang tersebuut meninggal dunia. Analisis biografi menggunakan analissi deskriptif untuk mengungkapkan kembali yang lebih dominan dengan sejarah penting dan jati diri seseorang yang menjadi objek analisis, seperti: Identitas diri, keturunan dan keluarga. Perkembangan hidupnya semasa kecil dan orangorang yang mempengaruhinya; Sejarah pendidikan dan masa pertumbuhannya menjadi dewasa; Sejarah pekerjaan dan reputasi Idiologi agama dan masyarakat yang mempengaruhinya; Ajaran-ajaran positif yang diperjuangkan; serta Harapan-harapannya yang akan datang. Lihat Sugiyono, Pendekatan Kuantitatif, Kualitatif, Kombinasi, R\&D Dan Penelitian Evaluasi, Metodologi Penelitian (Purwokerto: Percetakan Alphabet, 2017). 54-57
} 
Pulang ke rumah untuk mempersunting seorang gadis yang akan di jodohkan dengan AR Molou yang beliau sendiri belum mengetahui siapa wanita yang akan beliau nikahi. Pertemuan mereka tidaklah mudah seperti yang ada pada zaman sekarang ini melalui proses pacaran, dimana keduanya dipertemukan melalui perjodohan kedua orang tua dari masingmasing pihak keluarga, mereka berkenalan hanya lewat memperlihatkan telapak tangan dari wanita. Pernikahan pun berlangsung selama Tujuh hari Tujuh malam, Karena pada saat itu sesuai dengan adat kedua belah pihak memanglah orang terpandang atau yang memiliki nama di daerah Limboto (Halim A.R Molou, Wawancara pada 12 Juli 2020).

Latifah sendiri memang sudah memiliki pekerjaan sebagai Pegawai Negeri Sipil (PNS), di mana beliau adalah Bendahara di Dinas Kesehatan, dan kemudian menjadi Pesiunan di kantor Perternakan limboto Kabupaten Gorontalo. Dalam menjalankan rumah tangga pastinya akan menemukan lika-liku permaslahan untuk di jalani, tetapi dengan sikap sabar yang sudah tertanam dalam diri beliau, maka beliau mampu menjalankannya dengan menggunakan kepala dingin, ini di buktikan ketika beliau mengatasi masalah dengan istrinya beliau tidak pernah memperlihatkan kemarahan beliau kepada anak-anaknya, sehingganya disaat bertengkar mereka lebih sering menggunakan bahasa yang tidak mudah di mengerti anak-anaknya yaitu bahasa Arab dan bahasa Inggris. Seperti hasil wawancara dengan anak beliau Marwan Molou yaitu :

"Sering itu waktu ibu masih hidup, itu cuma dua bahasa yang mereka bahasakan, saya sering dengar itu, jadi kalo mereka marah kita tidak tahu karena berbahasa arab dan bahasa inggris (sambil tertawa) pernah saya juga bertanya "kenapa begitu opa"? katanya "tidak bagus orang tua bertengkar didengar sama anak-anak jadi bapak dan ibu harus berbahasa seperti itu" (Wawancara pada 12 Juli 2020).

Setelah menjalani bahtera rumah tangga kurang lebih selama 35 tahun lamanya, AR Molou harus melewati masa sulit beliau, dimana beliau harus mengikhlaskan istri beliau untuk kembali Rahmatullah tepatnya pada 24 juni tahun 1997, Mereka dianugrahi 5 orang anak oleh Allah SWT, yaitu 1 orang putri dan empat orang putra yaitu: 1) Mansur AR. Molou, berprofesi 
sebagai guru Penjaskes di Sekolah Luar Biasa, 2) Amna L. Molou, berprofesi sebagai Penyuluh Kemenag Talaga, 3) Halim A.R Molou, berprofesi sebagai Panitera Pengadilan Agama Gorontali, 4) Marwan Molou, berprofesi sebagai ADM MTs Negeri Kabupaten Gorontalo, 5) I san Molou yang berprofesi sebagai Tenaga ADM di KUA.

Setelah mengalami masa sulit selang kurang lebih seratus hari wafatnya ibu Latifah, AR Molou Ditawarkan oleh gabungan pemangku adat kabupaten dan pemangku adat kota Gorontalo untuk di Jodohkan dengan seorang wanita yang bernama Rusia S. Gobel atau yang sering di sapa dengan panggilan Ummi. Ummi sendiri memiliki latar belakang seorang anak dari pada mantan camat di Limboto dan Atinggola, beliau adalah keturunan terpandang yaitu keturunan marga Gobel. AR Molou ditawarkan untuk segera menikah karena beliau merupakan seorang Pemimpin, dan pemimpin harus memiliki seorang pendamping, pada saat itu Beliau kebingungan akan di nikahkan dengan siapa karena saat itu usia berusia 70 tahun. Maka melalui rapat para pemangku Adat AR Molou dipersandingkan dengan seorang wanita yang berusia 46 tahun. AR Molou menikah dengan Ibu Rusia Gobel pada bulan April 1997. Selama Pernikahan dengan Ibu Rusia Gobel, AR Molou selalu bersikap adil dalam menanggapi antara kelima anak kandung beliau dari istri pertama, dengan Ibu Rusia Gobel. Beliau selalu mengaskan kepada kelima anak-anaknya untuk selalu menganggap istri beliau sebagai ibu kandung. Seperti hasil wawancara peneliti dengan Marwan Molou sebagai anak keempat:

"Yah Alhamdulillah, sebagai syukuran saya pribadi saya anak yang keenpat, sampai beliau meninggal itu saya tidak mendapati ada istilah pilih kasih atau ada istilah setelah beliau meninggal kita di lupakan tidak ada seperti itu, bahkan beliau bilang sama kami "ini ibu tiri kamu ini, bapak berhutang nyawa kalau kamu menganggap dia sebagai ibu tiri kamu, jadi tolong jangan dianggap ini ibu tiri walaupun dia sebagai ibu tiri" dia bilang begitu. Jadi hubungan beliau dengan anak-anak sama seperi dengan hubungan dengan istrinya, begitu juga kita ketemu dengan ibu kita, kita panggil hari-hari dengan sebutan kesayangan "Ummi".

Hingga selama kurang lebih 21 tahun beliau bersama istrinya menjalani ikatan rumah tangga, AR Molou mulai mengalami sakit-sakitan 
yang membuat beliau memang sudah tidak bisa berbuat apa-apa, hanya bisa berbaring di tempat tidur dan berbicara seperlunya saja. Hingga pada saat seminggu beliau sebelum meninggal beliau selalu berpesan kepada anak-anaknya untuk tidak meninggalkan Sholat 5 waktu, dan tetap selalu mengingat Allah SWT. Seperti hasil wawancara Peneliti dengan Marwan Molou yaitu :

"Selalu dia pesan jangan lupa beribadah, dunia ini hanya sementara dan beliau itu kalau bicara sambil menangis. Dunia ini kecil kemudian kenapa kita membesarkan hati kita sementara dunia ini kecil. Maknanya untuk apa kita berbangga-bangga diri didunia sementara dihadapan Allah kita kecil." (Wawancara pada 13 Juli 2020)

Hingga pada akhirnya beliau harus berpulang ke Rahmatullah tepatnya pada tanggal 1 Dzulhijjah 1439 H/06 Agustus 2018 di umur beliau yang ke 95 Tahun. Hingga pada saat menjelang beliau wafat para pemangku adat mengadakan rapat untuk memberikan gelar Adat untuk AR Molou. Beliau memiliki gelar Adat yakni Ta'o Ilomata Ilo Masa yang artinya Putra Indonesia Terbaik Kelahiran Gorontalo yang Teguh Mengabdikan Dirinya di Bidang Hukum/Syariah, Pendidikan dan Kemasyarakatan Berdasarkan Wahyu Allah SWT dan Fi'il Rasulullah SAW. Jika diartikan Tao Ilomata adalah orang yang berhasil membuat karya besar karena banyak gagasan yang mampu beliau aplikasikan dalam kehidupan sehari baik dalam pendidikan maupun dalam kemasyarakatan. Sedangkan Ilo masa memiliki arti dua arti yaitu, yang pertama beliau memiliki banyak pendukung, dan sukses membuat kelompok besar untuk mendukung gagasan-gagasan yang beliau ciptakan, dan kedua ilo masa berarti seseorang yang memiliki karya yang akan dipergunakan dengan waktu yang cukup lama. Selain gelar adat ketika wafat beliau juga mendapatkan sajak adat Gorontalo pada saat pengantaran batu nisan untuk memberikan penghargaan setelah 40 hari beliau wafat yang kalimatnya dibuat sebelum almarhum disemayamkan untuk mengingat kebaikan dan kecintaannya kepada masyarakat dan orang banyak. Sajak ini dibuat oleh orang-orang tua dan tokoh adat melalui persetujuan keluarga yang berbunyi : 
Bismillahi Magafirati Lon To Allah Kudrati Ti Papa malo Wafati Dualo To tambati, Tadungga lowa pati mongo banta warisati hewolola lo sipati to delomo bele. Todulahiyo botiya wopato pulu huyiya paita malo butiya tinilo sairia. Monggo ahali ngaamila hiwunula lo ayuwa li papa lami puluwa olo mayi wuliluw. Ti papa ilohidiya aruwa upohadiya omoluwa oyiliya mongo banta sabaria. Ati ti Papa puluwa tiyo lowali tauwa mongo banta hiambuwa hipoduawa aruwa. Limo lota banta liyo Duluo Pulatuawo wombuliyo layito to dua liyo. Pohutu malo bulito botiya malo hulito dahayi bolo molonggito pusaka lai-laito, Pohuto lo darajati mongo banta taati pohile u barakati lo Allah magafirati, Pohutu lami botiya adati hunggiya kabatala siladia tuwotu tou mulia.

Terjemahnya: Bismillah Magfiroh dari allah papa kami telah wafat doakanlah di tempat., saat datangnya ajal anak-anak yang ditinggalkan dalam kerinduan hati didalam rumah kami. Pada hari ini keempat puluh hari batu nisan sudah tersedia dinyanyikan dengan syair. Para famili semua bertafakur diri pada papakandung kami hanya tinggal bayangan. Papa tempat bermanja doa arwah dihadiahkan kapan nampak lagi anak-anak tinggal dalam kesabaran. Papa banyak bergaul dengan keluarga yang benar jangan dilupakan doa arwah dipersembahkan. Kasihan papa kandung kami beliau jadi pemimpin anak-anak semua berkumpul mendoakan arwahnya. Lima orang anaknya dua puluh satu orang cucunya selalu dalam doanya. Sudah dibuat baik sekarang sudah diucapkan dijaga jangan terlepas pusaka adat berkesinambungan. Perbuatan yang baik anak-anak mentaati memohon doa dan berkah kepada allah yang magfirah, yang kami buat ini adalah adat kerajaan kebesaran tersedia tanda orang terhormat. (Halim A.R Molou, Wawancara pada 12 Juli 2020)

AR Molou merupakan panutan dan suri tauladan yang sangat di kenal masyarakat karena sikap ketawadhuan dan sifat tolong menolong beliau, banyak masyarakat yang memanggil beliau dengan sebutan " $A p a$ " yang berarti papa, panggilan ini biasanya digunakan oleh anak-anak angkat beliau, Beliau merupakan tempat bagi mereka untuk mempertanyakan dan menyelesaiakan segala bentuk problematika dan masalah, hebatnya beliau senantiasa menyampaikan jawaban-jawabannya yang senantiasa didasarkan pada syariat melalui Al-Quran dan hadist.

\section{Sepak Terjang dan Perjuangan AR Molou}


Untuk menjadi orang yang sukses tidaklah mudah, butuh perjuangan, doa dan kerja keras untuk mencapai suatu tujuan. AR Molou adalah seorang yang teguh dalam Prinsip dan cekatan dalam mengerjakan suatu tujuan yang ingin beliau capai. Banyak pencapaian telah beliau rintis, baik dalam bidang Masyarakat, keagamaan, sosial budaya maupun pendidikan. Dalam bidang kemasyarakatan sejak menjadi pemuda, beliau telah menjadi salah satu ketua pemuda Anshor dimana beliau sebagai penggerak para pemuda dan masyarakat pada masa itu untuk melawan para penjajah, beliau banyak mengajak masyarakat khususnya pemuda dimasanya dalam melawan para penjajah dengan tujuan mempertahankan tanah Gorontalo. Perjuangan beliau bersama Nani Wartabone pada tahun 1942 dalam memerdekakan Indonesia khususnya daerah Gorontalo pun pernah diberikan penghargaan sebagai salah satu pensiunan ABRI atau sebagai mantan veteran, namun karena beliau memiliki ciri khas pribadi yang tidak ingin menonjolkan kemampuan maka beliau menolak dengan alasan beliau hanya ingin berkarya dalam dunia pendidikan. Beliau mengajak para pemuda dan masyarakat untuk membantu para ABRI untuk melawan para penjajah, sehingga para pemuda dan masyarakat untuk melawan penjajah dengan Suka rela, demi mempertahankan bangsa, negara dan Suku Gorontalo. Selain dalam bidang kemasyarakatan dimana beliau pernah berjuang Untuk mempertahankan bangsa dan negara, terbawa hingga beliau berjuang dalam pendidikan, dimana beliau tetap gigih mempertahankan prinsip beliau untuk terus berkarya dalam pendidikan. Ini di buktikan dengan beliau mendirikan sekolah PG 4 dan PG 6 tahun pada tahun 1970 PG 4 tahun berarti setra dengan SMP dan PG 6 Tahun setara dengan SMA (Marwan Molou, Wawancara pada 9 Agustus 2020).

Bukan hanya memiliki ciri as karakter yang tawadhu, tetapi AR Molou juga meiliki sikap yang tawadhu, tetapi juga beliau memilki sikap yang dermawan dengan cara beliau mewakafkan Tanah yang telah beliau dirikan PG 4 tahun dan PG 6 tahun, Untuk Pembangunan Halaman Masjid Baiturahim. Tidak hanya berhenti pada PG 4 Tahun dan PG 6 Tahun, sekolah tersebut kemudian di pindahkan menjadi PGA di lahan yang sekarang sudah menjadi Universitas Gorontalo. Setelahnya sekolah 
tersebut di pindahkan lagi di lahan yang sekarang telah menjadi Universitas Muhamadiyah Gorontalo. Akan tetapi sekolah tersebut tidak bisa di kembangkan kembali karena kurangnya tenaga pengajar ususnya di bidang agama. Namun keinginan serta kegigihan AR Molou untuk mengembangkan dunia pendidikan beliau kembali merintis Pendidikan dengan memulainya melalui cara mendirikan Taman Pengajian Al-Qur'an (TPA) yang ber nama Attaqwa untuk lingkungan keluarga dan tetangga. Karena melihat situasi dan kondisi yang mendukung beliau untuk mengharuskan beliau mengembangkan TPA tersebut, maka Beliau memutuskan untuk mengembangkan TPA tersebut untuk di jadikan Madrasah, Yaitu Madrasah Tsanawiyah dan Aliyah Nuruttaqwa (Ali Pakaya, Sahabat AR Molou di NU, Wawancara 30 Juli 2020).

Madrasah Tsanawiyah dan Aliyah Nuruttaqwa yang didirikan pada tahun 1989 dan berkembang pada tahun 1991, sekolah ini pernah mengalami puncak kejayaannya yaitu pada tahun 1992 dengan memiliki jumlah peserta didik mencpai 100 lebih peserta didik, sehingganya AR Molou mengajak peserta didiknya untuk tinggal bersama beliau dirumahnya. Peserta didik tersebut selama tinggal di rumah AR Molou, bukan hanya di sekolah saja mereka mendapatkan pelajaran, beliau dengan gigih memberikan ilmu yang beliau dapatkan untuk di berikan kepada paserta didik beliau, dimana beliau mengadakan kajian-kajian Al-Qura'an, Fiqih, Tauhid, dan tasawuf. Dalam membangun Madrasah Tsanawiyah dan Madrasah Aliyah tersebut AR Molou tentu beliau tidak bisa mengembangkan sekolah tersebut dengan sendiri, oleh karena itu beliau di bantu oleh anak-anaknya terutama anak beliau Halim Molou, dan menggandeng NU agar sekolah tersebut bisa berkembang, dan ini terbukti dengan sekolah tersebut masih berdiri hingga saat ini. Jika bandingkan perkembangan sekolah tersebut saat peneliti masih duduk di bangku madrasah Tsanawiyah Nuruttaqwa pada tahun 2012 dengan kondisi yang sekarang, sudah banyak perubahah, terutama pada fasilitas-fasilitas yang ada saat ini. Semasa hidup beliau banyak gagasan-gagasan yang ingin beliau capai, hanya hanya banyak juga keterbatasan-keterbatasan yang 
beliau miliki. Gagasan-gagasan tersebut antara lain, seperti hasil wawancara peneliti dengan Marwan Molou :

"Saya pernah mendengar bahwa seandainya beliau ini punya lahan besar, maka saya mendirikan Perguruan Tinggi Nahdatul Ulama, sehingga saya pernah diajak untuk mencari tman-teman seperjuangan dengan beliau di Aswaja untuk menawarkan bekerja sama mendirikan pergunu, tapi Alhamdulillah walaupun beliau tidak sempat tapi sudah ada dari penguruspengurus Aswaja yang sekarang sehingga Pergunu sudah Ada." (Wawancara pada 12 juli 2020)

Bukan hanya dalam pembangunan Universitas saja tetapi beliau juga ingin membangun suatu tempat yang majadi pusat pengkajian Al-Qur'an dan hafalan Al-Qur'an yang saat ini gagasan tersebut sedang dijalankankan oleh anak beliau yaitu Halim Molou. Serta gagasan beliau lainnya yaitu beliau ingin mendirikan sebuah Panti Asuhan.

\section{Riwayat Pendidikan, Aktivitas Sosial, Keagamaan, dan Politik AR Molou}

Sejak kecil beliau sudah didik dalam keluarga yang taat pada perintah untuk beribadah kepada Allah SWT. Beliau diajarkan untuk tetap melaksanakan sholat lima waktu dan amar ma'ruf nahi Munkar. Sejak kecil beliau merupakan seorang anak yang sangat aktif. Memiliki seorang ibu yang sangat luar biasa dalam mengurusi pendidikan beliau tentunya sangat membantu beliau dalam jenjang pendidikan SD waktu itu, dimana ketika umur beliau belum cukup untuk masuk SD tetapi ibunya sangat berinisiatif untuk tetap menyekolahkan AR Molou dengan menitip beliau di bangku SD hingga beliau sudah cukup umur untuk di bangku SD. Dengan kecerdasan yaang luar biasa dimiliki beliau dimana beliau ketika kebanyakan siswa kelas satu belum bisa membaca tetapi beliau sudah memilliki kemampuan membaca tulisan Arab atau Al-Quran dan juga bisa membaca latin bahkan waktu beliau belum sekolah. maka beliau menjalankan masa sekolah SD nya hanya selama tiga tahun. 
Tiga tahun, tiga bulan di SD kelas satu langsung naik kelas dua, kemudian dua bualan di kelas dua langsung naik lagi di kelas tiga sehingga dalam kelas satu, dua, tiga hanya satu tahun baru ketika dia naik ke kelas empat hanya kira-kira empat bulan dikelas empat langsung dikasih naik kekelas lima begitu. setelah itu kelas enam dia ambil satu tahun. Kemudian beliau melanjutkan sekolah ke SMP seperti biasanya selama tiga tahun, dan ke SLTA Selama tiga tahun. Kemudian beliau ke SLTA lagi selama tiga tahun. Dengan menjalankan sekolah tentunya bukan hal mudah Ar Molou karena beliau harus mengalami lika liku perjuangan sekolah, dimana beliau harus jalan kaki ke sekolah beliau yang terletak di pusat kota gorontalo saat ini, setiap harinya beliau kebanyakan harus pulang pergi dengan jalan kaki untuk sampai ke sekolah.

Tetapi itu bukanlah hal yang dapat mematahkan semangat beliau dalam menjalankan pendidikan, karena semangat beliau meraih masa depan akan sangat membuahkan hasil, bukan hanya untuk dirinya sendiri tetapi untuk keluarga, masyarakat dan negara Indonesia. Setelah menyelesaikan sekolah SD, SMP, SLTA beliau, keluar daerah untuk memberikan ilmu yang beliau dapatkan. Setiap tempat yang beliau tempati akan meninggalkan perjuangan pendidikan, dimana beliau mendirikan sekolah, membuka TPA untuk anak-anak, berdakwah kepada masyarakat yang beliau temui. Kemudian melanjutkan kuliah pada tahun 1961 di kuliahtul mualimin IAIN Yogyakarta dan mengambil kelas jauh di Gorontalo, dan berhenti pada tahun 1963 tepatnya pada semester lima, yang di sebab beliau mendapatkan informasi dari teman-teman bahwa bapak AR Molou termasuk salah satu pemuda yang akan dibunuh oleh PKI pada masa itu, karena beliau adalah seorang pemuda pendakwah Islam yang luar biasa aktif dalam islam. Maka mendengar informasi tersebut, beliau memutuskan untuk berhenti kuliah tepatnya pada semester lima.

Dalam sosial bermasyarakat AR Molou merupakan panutan karena sikap beliau yang memang sudah tertanam dalam dirinya, kelebihan beliau adalah memiliki sikap yang tawadhu, suka tolong menolong dengan sesama serta memiliki kecerdasan yang luar biasa, sehingga menjadikan beliau sebagai salah satu panutan dalam dunia pendidikan. Adapun salah satu 
keunikan beliau seperti yang hasil wawancara peneliti dengan pak Marwan Molou:

"Ada kelebihan beliau yang saya lihat begini saya sempat saksikan beliau itu tidak pernah melihat orang itu masih muda, kalo ada orang berbicara ilmu, dia langsung ambil kertas, kebetulanbapak itu selalu bawa buku kecil dia bilang "nak kalo boleh kase sama saya itu ilmu kamu" dia tulis, mau ilmu umum, ilmu agama dia ambil."

Dalam bermasyarakat beliau bukan hanya bersikap tawadhu tetapi juga beliau dermawan dengan mewakafkan tanah untuk mendirikan masjid Baiturahman yang berada di keluahan kayu bulan kecamatan Limboto. AR Molou memiliki seorang paman pendakwah, sehingga tidak sedikit pribadi pamannya tersalurkan dalam sikap beliau. AR Molou sudah terlatih dengnan sikap yang keluarga beliau terapkan. Akan tetapi berdakwah, bukanlah hal yang mudah untuk dijalankan karena ada tanggung jawab yang harus beliau terima untuk setiap perkataan yang beliaua ucapkan. Oleh karenanya AR Molou mempelajari ilmu bukan hanya sekedar membaca tetapi beliau juga menerapkan dalam kehidupan sehari-harinya. Beliau berdakwah bukan hanya melalui perkataan melainkan memberikan contoh yang baik untuk di jadikan panutan. Pada saat beliau mengajar dalam kelas, beliau sangat bersikap familiar dan kekaluargaan dimana beliau mengajak anak-anak didiknya dengan penuh kesabaran dan kehatihaitian. Beliau memiliki prinsip dalam mengajar dan beliau selalu mengatakan kepada setiap guru yang beliau temui dan memberiakan tiga cara untuk menghadapi sikap siswa yaitu : yang pertama: jangan menyakiti fisiknya, yang kedua: jangan menghinakan derajatnya, dan yang ketiga: menimbulkan kecintaan nya kepada ilmu dan orang tua. Seperti yang di katakan oleh salah satu Rustam Yahya Alumni dari PG empat dan PG Enam :

"Beliau adalah panutan kami, orang yang memiliki dedikasi yang luar biasa terutama bagi kemajuan pendidikan, bayangkan saja hampir seluruh tenaga, uang dan bahkan gajinya dibelanjakan untuk kepentingan pendidikan, sampai saat ini sangat sulit untuk menemukan orang yang seperti beliau, ikhlas lillahi ta'ala" Wawancara, 15 Juli 2020) 
Melalui sikap rendah hati yang dimiliki beliau tanpa harus dimintapun setiap orang yang melihat beliau akan sangat menghormati dan segan dengan beliau, mereka melihat beliau bagaikan sahabat rosul melihat rosul. Begitupun dengan beliau, dengan sikap tawadhu yang dimiliki beliau membuat setiap orang melihat beliau dengan penuh kecintaan. Karena beliau sering memberikan contoh bagaimana untuk menghargai orang lain, sehingga orang lain pun mudah untuk menghargai. Semasa Hidup beliau, Ar Molou bukan hanya aktif menjadi seorang tenaga pendidik, beliau juga pernah menjadi hakim istimewah setelah masa pensiun beliau di tahun 1988 beliau juga pernah menjadi hakim setelah pensiun sebagai Pegawai negeri Sipil (PNS), beliau di minta oleh pengadilan Agama limboto untuk menjadi hakim istimewa karena pada saat itu kantor pengadilan agama masih membutuhkan hakim ulama sebagai pemutus perkara. Selang satu tahun beliau menjadi hakim beliau memutuskan untuk berhenti menjadi hakim karena harus mengasuh kembali sekolah yang telah beliau bangun yaitu pada tahun 1989 dan berkembang pada tahun 1991 yaitu Madrasah Tsanawiyah dan Madrasah Aliyah Nuruttaqwa Limboto (Halim A.R Molou, Wawancara pada 12 Juli 2020).

Selain sebagai Hakim dan pendidik beliau juuga pernah menjadi sseorang Qodhi selama kurang lebih 20 tahun. Di mana beliau bertugas sebagai Pemangku adat Gorontalo dalam bidang keagamaan. Selain bersikap tawadhu beliau juga memiliki sikap yang dermawan, dimana beliau mewakafkan tanah yang pernah beliau dirikan sekolah PG 4 tahun dan PG 6 tahun untuk pembangunan masjid Baiturrahman Limboto. Beliau juga menjadi imam Masjid di masjid Baiturahman Limboto, selama 10 tahun. Selain itu juga beliau pernah menjadi kepala kantor urusan agama selama dua periode kurang lebih sepuluh tahun. Beliau juga pernah berkiprah menjadi seorang ulama aktif Nahdatul Ulama. Bukan hanya dalam aktivitas di luar saja, tetapi beliau juga aktiv dalam kehidupan seharhari beliau,beliau rajin dan tekun membaca beberapa buku. Beliau tidak 
pernah mengisi waktu beliau denga hal-hal yang tidak bermanfaat beliau mengisi waktu beliau dengan membaca buku antara lain yaitu: ${ }^{8}$

1. Sirrul Asrar, kitab inti segala Rahasia Kehidupan oleh Syai Abdul Qodir Al-Jailani.

2. Ailul Authar, kitab etika/a lak, dan motivasi ibadah oleh Imam AsySyau ani.

3. Riyadh Al-Shalihin, taman orang-orang shaleh oleh Imam Nawawi.

4. Tanbihul Ghafilin, peringatan kepada orang yang lupa, oleh Abu Laits As-Samarqandi.

5. Ihya' Ulumuddin, upaya menghidupkan Agama, oleh imam Al-Ghazali.

Lima buku tersebut adalah-buku-buku yang sering beliau baca, dan banyak lagi buku yang sering dibaca namun sayangnya menurut keluarga beliau buku lainnya sudah hanyut karena banjir di rumah beliau sehingganya beberapa diantaranya yang tersisa yaitu: 1) Fiqih Sunah, Karya Sayyid Sabiq, 2) Al-Munjid atau kamus Al-Quran, 3) Sahiril Ahqam. Sepak terjang AR Molou dalam dunia politik di Gorontalo pun cukup menarik, beliau pernah menjadi Tokoh Nahdatul ulama, dan berperan sebagai orang yang memberikan pembinaan-pembinaan pada regenerasi. Pada masa beliau menjadi Ulama dalam NU beliau tidak terlalu mendalami bidang politik, tetapi beliau tetap berperangai dalam memberikan pembinaan atau meluruskan kekeliruan dalam pemahaman, ataupun keyakinan dalam NU. Dalam hubungan dengan politik lain beliau tidak diskriminasi dengan Organisasi lain termasuk juga dengan Muhamadiyah, beliau tidak terlalu menggubris hal-hal yang dapat merusak ketabahan beliau dalam merintis tugasnya.

Pada tahun 1971 organisasi NU pernah masuk dalam partai politik, baik PDI, Golkar, Demokrasi dan partai lainnya, tetapi hal ini di berhentikan dan kembali ke titah 26 karena NU adalah Organisasi masa bukan organisasi politik. Untuk menjadi kader dalam bidang politik partai Golonga Karya diambil dari tiga jalur yaitu ABG, A artinya ABRI, B artinya Beringan dimana pada masa itu PNS ataupun Ulama di haruskan

\footnotetext{
${ }^{8}$ Amna I, Molou, Wawancara pada 20 Juli 2020 
untuk terjun dalam Bidang politik. Pada masa itu AR Molou termasuk dalam politik di karenakan beliau termasuk dalam pegawai negeri sipil dan termasuk ulama yang memaksakan beliau harus terjun langsung untuk merintis tugas dalam politik Golkar, sehingganya beliau di tunjuk untuk menjadi juru kampanye dengan berlandaskan ajaran-ajaran Nahdatul Ulama. ${ }^{9}$

\section{Karya dan Prestasi AR Molou Semasa Hidup}

Semasa hidup AR Molou memiliki beberapa karya intelektual dalam bentuk tulisan, beliau juga sering mengekspresikan keilmuan dan keintelektualitasannya melalui transformasi ilmu kepada para siswanya ataupun pada masyarakat. Beliau pernah membangun sekolah pada tahun 1970an yaitu PG empat tahun, PG enam tahun, PG GUPI yang kemudian sekolah ini berhenti karena tidak ada lagi perintis yang melanjutkannya, tetapi peneliti menemukan beberapa bukti dari siswa-siswa yang pernah menjadi alumni dari sekolah tersebut. Peneliti mendapatkan informasi ini melalui seorang Alumni dari PG empat Tahun, dan PG enam tahun yaitu Ali Pakaya yang menjadi siswa beliau dari tahu 1970-1976. Kegigihan beliau tidak berhenti pada sekolah itu saja, beliau melanjutkan perjuangan beliau melanjutkan membangun taman pengajian Al-Qur'an dan mengembangkannya menjadi madrasah aliyah dan Madraah tsanawiyah Nuruttaqwa pada tahun 1989 dan mendapatkan pengakuan dari pemerintah pada tahun $1991 .^{10}$

Bukan hanya dalam dunia pendidikan, gagasan AR Molou juga banyak di gunakan oleh masyarakat, baik dalam segi politik maupun pembangunan daerah gorontalo. Gagasan yang beliau utarakan di jadikan sebagai patokan nasehat-nasehat maupun arahan untuk di kembangkan oleh masyarakat. Beliau juga memiliki banyak penghargaan, tetapi sangat disayangkan ada beberapa piagam beliau yang tidak terselamatkan karena

\footnotetext{
${ }^{9}$ Ali Pakaya, Wawancara pada 22 Juli 2020

${ }^{10}$ Halim A.R Molou, Wawancara pada 12 Juli 2020
} 
adanya banjir di tempat tinggal beliau. Sehingganya hanya tersisa beberapa piagam diantara lain: ${ }^{11}$

1. Piagam Penghargaan, Ulipu Lo Limutu To Boungo berdasarkan musyawarah adat pada tanggal 07 Agustus 2018/25 dzul qoidah 13439 $\mathrm{H}$.

2. Piagam haji : piagam ini di berikan untuk kenang-kenangan dan sebagai bukti bahwa Ar Molou telah menunaikan ibadah haji pada tahun 1425 H/2005 M di Mekkah Al-Mukarromah.

3. Tanda Penghargaan atas partisipasi AR Molou dalam Pelaksanaan Research "Hubungan Mahkamah Agung dengan Badan-badan peradilan agama di Gorontalo dari 1 propinsi Sulawesi Utara pada tanggal 26 Juli 1978

4. Piagam : AR Molou telah mengikuti dengan baik penetaran yang telah diselenggarakan oleh panitia pada tanggal 25 s/d 28 Agustus 1975 di manado berdasarkan suat instruksi direktur Utama Agam Ditjen Bimas Islam selaku Ketua BP 4 pusat tanggal 28 Juli 1975 Nomor 178/6-P/BP 4/7/75 disertai harapan dapat mengamalkan segala ilmu pengetahuan yang telah diperolehnya dalam melaksanakan tugas selaku Pengurus BP4 di daerahnya masing-masing.

5. Tanda penghargaan atas prestasi Ar Molou dalam merayakan/mengikuti perlombaan serta turut memberikan bantuan dalam rangka peringatan HUT Ke XII Golongan Karya kabupatn Dati II Goronttalo Tanggal 20 oktober 1976 sebagai juara 1 Penitia penyelenggara dalam cabang perlombaan Seni Baca Al-Quran.

6. Piagam atas keberhasilan Ar Molou mengikuti penataran Juru Kampanye Golkar Kabupaten daerah TK II Gorontalo yang diselenggarakan tangggal 12-14 juli 1978 di limboto.

7. Tanda penghargaan atas pengabdian Ar Molou sebagai Hakim agama/anggota tidak tetap dalam membantu kelancaran pelaksanaan sidang-sidang pada Pengadilan agama di Limboto pada juni 1990.

\footnotetext{
${ }^{11}$ Marwan Molou, Wawancara pada 23 Januari 2019.
} 
8. Sertifikat Badan Koordinasi Keluarga Berencana Nasional, bahwa Ar Molou Telah mengikuti Orientasi Program KB bagi Toma, Toga dari $\mathrm{Kab} /$ Kota se-Provinsi Gorontalo.

9. Sertifikat yang diberikan kepada AR Molou/ Kadli Limboto sebagai peserta pada kegiatan seminar adat Gorontalo Dengan tema "Pengembangan dan pemberdayaan Adat Demi Terwujudkan kesejahteraan Rakyat", yang dilaksanakan oleh Pemerintah Daerah Kab. Gorontalo kerjasama dengan Forum Pengkajian Islam. dari tanggal 06-07Agustus 2007 bertempat di Gedung Kasmat Lahay Limboto.

\section{Sumbangsih Pemikiran AR Molou dalam Memajukan Sistem Pendidikan Islam di Gorontalo}

Pendidikan islam menurut AR Molou adalah fardhu ain bagi yang menampaikan dan fardhu ain bagi yang menerima. Ornag yang menyampaikan ilmu islam akan menjadi orang yang sebaik-baiknya orang di muka bumi. Seperti yang di jelaskan dalam Al-Quran surah Al-Imran ayat 110 yang artinya sebagai berikut :

Kamu adalah umat yang terbaik yang dilahirkan untuk manusia, menyuruh kepada yang ma'ruf, dan mencegah dari yang munkar, dan beriman kepada Allah. Sekiranya ahli kitab beriman, tentulah itu lebih baik bagi mereka, di antara mereka ada yang beriman, dan kebanyakan mereka adalah orangorang yang fasik.

Beliau juga berpendapat manusia yang tinggal di muka bumi ini membutuhkan peta, orang dengan peta akan lebih pasti jalan yang harus di tempuh untuk sampai pada tujuan, peta yang dimaksud adalah Al-Quran dan hadist rosulullah. Kemudian hidup didunia harus memerlukan cahaya, agar kita dapat melihat mana yang benar dan mana yang salah, maka cahaya untuk hidup didunia adalah dengan ilmu. ${ }^{12}$ Ilmu menurut beliau ilmu adalah pnyelmat iman, maksudnya adalah orang yang berilmu dapat menjaganya untuk berhati-hati dlam melakukan nahi mungkar. Dengan

\footnotetext{
${ }^{12}$ Halim A.R Molou, , wawancara pada tanggal 12 juli 2020
} 
menuntut ilmu Agama dapat membantu manusia beribadah dengan sempurna untuk berjalan menuju syurga.

Selain dari itu AR. Molou berasumsi bahwa pendidikan merupakan merupakan kunci untuk menapaki masa depan. Pendidikan menjadi penting artinya karena melalui pendidikanlah yang menentukan arah kehidupan melalui proses pembelajaran antar generasi ususnya di Gorontalo. Melaui proses sosialisasi, enkulturasi di dalam institusi primer yaitu dalam keluarga. Dari situlah proses pewarisan unsur budaya dalam hal ini adalah pembelajaran dilakukan pertamakali. Sedemikian pentingnya pendidikan dalam hidup, maka pendidikan selalu menjadi ranah selalu hangat untuk diperbincangkan.Hal yang menarik lagi dalam diskursus mengenai tema besar ini adalah pijakan akar budaya dan historisitas dari perkembangan pendidikan di Indonesia. Suatu kondisi yang tidak boleh tidak ada seandainya kita mau meneliti tentang perkembangan pendidikan di negeri kita ini adalah faktor kesejarahan.Bagaimanapun juga sejarah warisan kolonial Belanda turut membentuk wajah pendidikan Indonesia.

AR. Molou merumuskan konsep pendidikan Islam, dengan mengkaitkan Islam sebagai disiplin ilmu. Dalam upaya membangun ataua merekonstruksi pendidikan Islam di Gorontalo, beliau menawarkan gagasan untuk senantiasaa memperhatikan prinsip-prinsip pendidikan Islam, yang meliputi:

1. Pendidikan Islam di Gorontalo merupakan bagian dari sistem kehidupan Islam secara keseluruhan, yaitu suatu proses internalisasi dan sosialisasi nilai-nilai moral Islam melalui sejumlah informasi, pengetahuan, sikap, perilaku dan budaya masyarakat Gorontalo,

2. Pendidikan Islam di Gorontalo merupakan sesuatu yang integrated artinya mempunyai kaitan yang membentuk suatu kesatuan yang integral dengan ilmu-ilmu yang lain,

3. Pendidikan Islam di Gorontalo merupakan life long process sejak dini kehidupan manusia

4. Pendidikan Islam di Gorontalo berlangsung melalui suatu proses yang dinamis, yakni harus mampu menciptakan iklim dialogis dan interaktif antara pendidik dan peserta didik. 
5. Pendidikan Islam di Gorontalo dilakukan dengan memberi lebih banyak mengenai pesan-pesan moral pada peserta didik. Prinsip-pinsip di atas akan membuka jalan dan menjadi fondasi bagi terciptanya konsep pendidikan Islam. Dengan tawaran prinsip inilah, konsep pendidikan Islam lebih pas apabila diletakkan dalam kerangka pemahaman, bahwa pendidikan Islam adalah pendidikan menurut Islam, bukan pendidikan tentang Islam.

Lebih lanjut dalam pemikiran AR. Molou Pendidikan Islam di Gorontalo hendaknya bukan saja berusaha meningkatkan kesadaran beragama, melainkan juga untuk melihat perubahan-perubahan sosial dalam perspektif transedental, dan menempatkan iman sebagai sumber motivasi perkembangan dalam menyelami dan menghayati ilmu pengetahuan modern. Artinya bahwa dalam proses pendidikan Islam terkandung upaya peningkatan kemampuan mengintegrasikan akal dengan nurani dalam menghadapi masalah perubahan sosial. Dengan begitu diharapkan pendidikan Islam lokal di Gorontalo dapat memenuhi fungsinya dalam menghadapi perkembangan sosial, apabila dalam proses KBM menggunakan pola pengajaran innovative learning, yakni: (1) berusaha memupuk motivasi yang kuat pada peserta didik untuk mempelajari dan memahami kenyataan-kenyataan sosial yang ada, (2) berusaha memupuk sikap berani menghadapi tantangan hidup, kesanggupan untuk mandiri dan berinisiatif, peka terhadap kepentingan sesama manusia dan sanggup bekerja secara kolektif dalam suatu proses perubahan sosial. Allah Swt berfirman dalam Q.S. Al-Hasyr ayat 18 yang artinya:

Hai orang-orang yang beriman, bertakwalah kepada Allah dan hendaklah Setiap diri memperhatikan apa yang telah diperbuatnya untuk hari esok (a irat); dan bertakwalah kepada Allah, Sesungguhnya Allah Maha mengetahui apa yang kamu kerjakan

Makna ayat diatas dapat dipahami dalam artian bahwa Allah Swt meninggalkan suatu pesan bagi manusia agar dapat menuju kemasa depan yang lebih baik, maka seseorang haruslah memperhatikan apa yang telah dan sedang terjadi di masyarakat. Hal ini tentu saja terkait dengan upaya menyadap sebanyak mungkin informasi, kemudian menganalisisnya. 
Heteroginitas informasi yang telah disadap yang kemudian ditindaklanjuti dengan pengolahan dan interpretasi akan menumbuhkan kemampuan berpikir secara holistik dan integratif. Bila kemampuan ini telah dimiliki seseorang, maka untuk mengantisipasi perubahan yang menumbuhkan kesadaran internal dan ketrampilan memecahkan masalah bukannya sesuatu yang memberatkan. Adalah bukan tidak mungkin, bahwa persoalan informasi mempunyai korelasi akseptabilitas dengan dunia pendidikan, bahkan dengan fungsi informasi, pendidikan Islam akan mampu mengimbangi kemajuan zaman. Korelasi ini terletak pada persoalan substansi materi pendidikan Islam itu sendiri. Dalam spektrum yang lebih makro, seberapa jauh alih nilai moral mampu membekali peserta didik untuk menghadapi sekaligus memecahkan persoalan secara proporsional sekaligus mampu mengembangkan budaya religius. Spektrum tersebut menuntut peran pendidik (guru, dosen) untuk mampu tampil lebih profesional di hadapan peserta didik dengan menyertakan menu-menu materi yang bersifat kontekstual, dinamis dan berorientasi ke masa depan.

Semua ini akan didapatkan jika tradisi menyadap banyak informasi menjadi tuntutan setiap saat bagi para pendidik. Pendidikan sebagai proses penyiapan peserta didik agar memiliki kemampuan mengantisipasi persoalan hari ini dan esok harus dilihat dari dimensi informasi. Dengan kata lain, kemampuan tersebut akan dicapai hanya melalui intensitas mencari, mengolah dan mengintepretasikan informasi. Menguasai informasi hari ini berarti mampu menguasai informasi hari esok. Menguasai permasalahan hari ini berarti menguasai permasalahan hari esok. Sekarang dan esok sebenarnya bersifat saling berkaitan dan merupakan jaringan-jaringan masalah yang kompleks meski dengan tingkat kompleksitas yang beragam. Dengan gelombang informasi, maka proses belajar-mengajar akan terhindar dari diskontinuitas kesejarahan dan sistem nilai dalam pendidikan kemarin, sekarang dan esok. Sehingga pendidikan sebagai alih nilai (transfer of value) tidak hanya memberi materi sesuai dengan program of studies yang ada dalam jadwal kelas, tetapi yang lebih penting adalah bagaimana mengkondisikan lingkungan yang 
memungkinkan dirinya secara optimal dan menjadi berkualitas tinggi sesuai tuntutan zaman. ${ }^{13}$

Suatu problematika yang sangat menghambat gerak dan pertumbuhan pendidikan di Gorontalo menurut AR. Molou adalah fenomena dikotomi/dualisme ilmu, dimana fenomena tersebut merupakan suatu hal yang tidakdapat dipungkiri keberadaannya terlebih cenderung nampak seperti suatu masalah yang diwariskan turun-temurun sejak dahulu dalam dunia pendidikan Islam. Analisis penulis dalam pandangan AR. Molou bahwa dikotomi merupakan suatu istilah yang dipakai mencerai beraikan antara karakter ilmu agama dan umum yang seakan digunakan secara terpisah. Lanjutnya bahwa hal ini tidak lepas dari latar belakang historiskultural, di mana dalam proses pertumbuhannya ada pemisahan yang demarkatis antara kedua item tersebut. Dalam konteks pendidikan Islam, dikotomi lebih dipahami sebagai dualisme sistem pendidikan antara pendidikan agama Islam dan pendidikan umum yang memisahkan kesadaran keagamaan dan ilmu pengetahuan. Sistem pendidikan yang dikotomik pada pendidikan Islam akan menyebabkan pecahnya peradaban Islam dan akan menafikan peradaban Islam yang kaffah dan universal. ${ }^{14}$ Lanjut menurut AR. Molou dikotomi dalam pendidikan Islam timbul akibat dari beberapa hal yaitu:

1. Akibat sejarah dari perkembangan umat Islam ketika mengalami masa kemunduran sejak Abad Pertengahan (tahun 1250-1800 M), yang pengaruhnya bahkan masih terasa sampai kini bahkan bagi dunia pendidikan di Gorontalo, pada era ini dominasi pendidikan Islam sangatlah kuat, sehingga terjadi kristalisasi anggapan bahwa ilmu agama tergolong fardlu 'ain atau kewajiban individu, sedangkan ilmu umum termasuk fardlu kifayah atau kewajiban kolektif. Terlebih dialektika masyarakat Gorontalo sangat memegang teguh jargon dan prinsip syariat dengan sangat kuat, semboyan (1) Adati Hula-Hula'a To Syara'a

\footnotetext{
${ }^{13}$ Kutipan penuh lihat Baharom Mohamad, Ali Suradin, and Za'aBa Helmi Khamisan, "Peranan Pendidikan Islam Dan Pendidikan Moral Dalam Membina Sahsiah Pelajar Berkualiti," Dalam Persidangan Pembangunan Pelajar Peringkat Kebangsaan Universiti Teknologi Malaysia (2008).

${ }^{14}$ Muhamad Mustaqim, "Pengilmuan Islam dan Problem Dikotomi Pendidikan A . Pendahuluan Dalam Sebuah Diskusi Ilmiah di STAIN Kudus Beberapa Waktu Lalu , Yudian Wahyudi, Guru Besar UIN Sunan Kalijaga Yogyakarta Menyatakan Bahwa Ilmu Islam Yang Sekarang Ini Kita Warisi Te” 9, no. 2 (2015): 255-274.
} 
(adat bersendikan syarak; (2) Adati Hula-Hula'a To Syara'a, Syara'a HulaHula'a To Adati (adat bersendikan syarak dan syarak bersendikan adat); (3) Adati Hula-Hula'a To Syara'a, Syara'a Hula-Hula'a To Kitabi (adat bersendkan syarak dan syarak bersendikan al-Qur'an, hadis Nabi saw, ijmak dan qiyas), menjadi bukti otentik bahwa nilai agama merupakan prioritas yang sangat dikultuskan lebih dari apapun. Akibatnya, umat islam di Gorontalo lebih mengutamakan pendidikan agama dibandingkan pendidikan ilmu pengetahuan dan teknologi.

2. Ketiga, faktor internal kelembagaan pendidikan Islam yang kurang mampu melakukan upaya pembenahan dan pembaruan akibat kompleksnya problematika ekonomi, politik, hukum, sosial dan budaya yang dihadapi umat dan negara yang berpenduduk mayoritas Islam. Sehinggga, dalam lembaga pendidikan Islam di Gorontalo tidak terjadi dikotomi ilmu agama dan ilmu umum. Sebenarnya, asumsi mengenai dikotomi ini, bukanlah monopoli lembaga pendidikan. Krisis kelembagaan ini adalah adanya dikotomisasi antara lembaga-lembaga pendidikan yang menekankan pada salah satu aspek dari ilmu-ilmu yang ada, apakah ilmu-ilmu agama ataukah ilmu-ilmu umum. Ini jelas sekali terefleksi di Gorontalo, misalnya dengan adanya dulaisme sistem pendidikan, pendidikan agama yang diwakili madrasah dan pesantren dengan pendidikan umum. Hal ini dapat pula berimpilkasi mulai dari segi pendanaan pendidikan yang dibawah naungan Diknas dan Depag sangat jauh berbeda, sehingga hal ini pula dapat berimplikasi pada penunjang sarana dan prasarana.

Implikasi dikotomi pendidikan di Gorontalo ini bagi AR. Molou merupakan pukulan besar yang sudah lama harus segera diselesaikan, diantara dampak negatifnya :

1. Memunculkan sikap antipati terhadap agama berkaitan dengan aspek teologi Islam yang diajarkan disekolah-sekolah agama selama ini.

2. Sekolah agama telah terkotak dalam kubu-kubu tersendiri sehingga mengalami keterasingan dan degradasi ideologi. 
3. Sumber masukan sekolah agama rata-rata ber-IQ rendah, maka mutu tamatannya adalah tergolong kelas dua

4. Kegiatan keagamaan dan api keislaman dalam dunia pendidikan agama Islam di Gorontalo kurang menonjol dan kurang dirasakan dibandingkan dengan lembaga pendidikan umum lainnya.

AR. Molou menganggap bilamana konsep dualisme dikotomik pendidikan di Gorontalo mampu untuk diselesaikan, kemungkinan bahwa dalam masa jangka panjang eksistensi dan sistem pendidikan Islam di Gorontalo juga akan berubah secara keseluruhan, mulai dari tingkat dasar sampai ke perguruan tinggi. Menurut Ramayulis, solusi mengurangi atau mentiadakan dikotomi dalam pendidikan dengan berpedoman kepada prinsip-prinsip keseimbangan yang mendasari pendidikan Islam yaitu keseimbangan antara kehidupan duniawi dan u rawi, keseimbangan antara jasmani dan rohani serta keseimbangan antara individu dan masyarakat. Menurut Kamal Muhamad Isa, kesalahan utama manusia yang selama ini berlangsung terus menerus adalah adanya pemisahan antara ilmu dan agama, bahkan agama dianggap sebagai musuh ilmu, penghalang ilmu, atau paling banter hanya dianggap sebagai pengganti ilmu. Padahal agama merupakan kerangka dasar dari setiap ilmu pengetahuan dan kebudayaan, yang menjadi sumber bagi pertumbuhan ilmu pengetahuan dan kebudayaan itu sendiri. Agama merupakan satu-satu dasar dan sumber yang mengatur seluruh permasalahan kehidupan manusia. Orang yang belajar al-Quran dengan cermat dan teliti akan menemukan sebagian ayatnya yang disebut berbagai fakta dan peristiwa sebagai muqaddimah yang kemudian sampai kepada Allah sebagai suatu keputusan yang disebut ilmu teory, sementara ayat-ayat yang menyatakan kehidupan merupakan topik dari ilmu pengetahuan dinamakan ilmu praktis. ${ }^{15}$

AR. Molou dalam ranah implementasi senantiasa mengedepankan integrasi Ilmu dalam menghadapai dikotomi yang ada di dunia pendidikan Gorontalo selama ini, dimana pendidikan Islam selalu saja menjadi

\footnotetext{
${ }^{15}$ Waston Waston, "Pemikiran Epistemologi Amin Abdullah Dan Relevansinya Bagi Pendidikan Tinggi Di Indonesia," Profetika: Jurnal Studi Islam (2016).
} 
prioritas kedua dan cenderung terkesan tidak bonavit sama sekali, hal ini terlihat dari bagaimana sistem pendidikan yang berusaha di bangun melalui yayasan MTS dan MA Nuruttaqwa, yang cenderung mengusung keseimbangan konsep spiritual dan ilmu pengetahuan modern (Tekhnologi). AR. Molou menjadikan tidak ada sekat diantara kedua domain tersebut dalam proses pembentukan karakter dan keilmuan para siswa-siswanya. Upaya ini dilakukan agar dapat melahirkan kader umat yang siap pakai di masyarakat, yang intelek dan ulama, atau ulama yang intelek.

Dalam konteks ini penulis melihat, agaknya pemikiran AR. Molou sejalan dengan konsep yang ditawarkan oleh Al-Faruqi yaitu upaya untuk membangun Islamisasi ilmu dalam pendidikan Islam, yakni dengan melebur dua sistem pendidikan; tradisional dan modern, menjadi sistem pendidikan yang berwawasan Islam. Ini dimaksudkan untuk menghilangkan masalah dikotomi sistem pendidikan yang selama ini serinkali terjadi di kalangan umat. Ide "Islamisasi Ilmu" dalam pendidikan Islam berisikan suatu prinsip; bahwa keilmuan Barat tidak harus ditolak, artinya perlu diterima, tetapi harus melalui proses filterisasi yang disejalankan dengan nafas Islami agar tidak bertentangan dengan pesan alQuran dan al-Hadits. Peran islamisasi ilmu dalam pemecahan problem dikotomi pendidikan islam adalah spirit yang ditawarkan al-Faruqi dalam rangka memecahkan problem dikotomi pendidikan Islam adalah Islamisasi Ilmu dalam pendidikan Islam. ${ }^{16}$ Menurut penulis pada bagian ini, pemikiran AR. Molou banyak mengadopsi pemikiran pendidikan para tokoh raksasa di dunia pendidikan Islam, dimana para akademikus muslim harus menguasai semua disiplin ilmu modern, memahami disiplin tersebut dengan sempurna, dan merasakan itu sebagai perintah agama. Setelah itu mereka harus mengintegrasikan pengetahuan baru tersebut ke dalam keutuhan warisan Islam dengan melakukan eliminasi, perubahan, penafsiran kembali, dan penyesuaian terhadap komponen-komponennya sebagai world view Islam dan menetapkan nilai-nilainya.

\footnotetext{
${ }^{16}$ Parluhutan Siregar, "Integrasi Ilmu-Ilmu Keislaman Dalam Perspektif M. Amin Abdullah,” Miqot: Jurnal Ilmuilmu Keislaman (2014).
} 


\section{Kesimpulan}

AR Molou merupakan salah satu tokoh pendidikan islam di Gorontalo, selain menjadi guru pendidikan agama, beliau juga banyak berkecimpung di dunia dakwah sebagai da'i, perpolitikan sebagai jurkam Golkar, organisasi sebagai pengurus NU, bahkan beliau pernah menjadi Kepala Urusan Agama, seorang Da'i, Hakim Pengadilan Agama, dan juga pegawai Syara' sebagai Qadhi. Beliau adalah tokoh dan panutan yang sangat menginspirasi generasi setelahnya dan telah mengabdikan seluruh hidupnya demi pendidikan, atas pengabdian dan jasa-jasanya tersebut beliau dianugerahi 9 piagam penghargaan. Adapun sumbangsih pemikiran beliau dalam memajukan geliat pendidikan Islam di Gorontalo yang paling berpengaruh adalah konsep integrasi antara ilmu dan agama yang telah lama terdikotomi, entah itu diakibatkan oleh eskalasi perpolitikan lokal dan nasional atau bahkan implikasi oleh sisa-sisa doktrin negatif warisan yang ditinggalkan oleh kolonial. Dalam ranah implementasi-pun beliau mempraktikannya langsung dengan mendirikan yayasan MTS dan MA Nuruttaqwa, yang cenderung mengusung keseimbangan konsep spiritual dan ilmu pengetahuan modern (Tekhnologi), serta berupaya menghancurkan sekat diantara kedua domain tersebut dalam proses pembentukan karakter dan keilmuan bagi anak didiknya. Upaya ini dilakukan agar dapat melahirkan kader umat yang siap pakai di masyarakat, yang intelek dan ulama, atau ulama yang intelek.

\section{DAFTAR PUSTAKA}

Baharom Mohamad, Ali Suradin, And Za'aba Helmi Khamisan. "Peranan Pendidikan Islam dan Pendidikan Moral Dalam Membina Sahsiah Pelajar Berkualiti." Dalam Persidangan Pembangunan Pelajar Peringkat Kebangsaan Universiti Teknologi Malaysia (2008).

Gumilang, Galang Surya. "Metode Penelitian Kualitatif Dalam Bidang Bimbingan dan Konseling." Jurnal Fokus Konseling 2, No. 2 (2016). 
Gunawan, Imam. "Metode Penelitian Kualitatif: Teori Dan Praktik." Jakarta: Bumi Aksara, 2014.

Mustaqim, Muhamad. "Pengilmuan Islam Dan Problem Dikotomi Pendidikan A . Pendahuluan Dalam Sebuah Diskusi Ilmiah Di Stain Kudus Beberapa Waktu Lalu, Yudian Wahyudi, Guru Besar UIN Sunan Kalijaga Yogyakarta Menyatakan Bahwa Ilmu Islam Yang Sekarang Ini Kita Warisi Te" 9, No. 2 (2015).

Panigoro, M Rifian, And Abdur Rahman Adi Saputera. "Implementasi Metode Sam'iyah Syafahiyah Pada Siswa Sebagai Upaya Meningkatkan Kemampuan Penguasaan Mufradat." A Jamiy: Jurnal Bahasa Dan Sastra Arab 9, No. 2 (2020).

Parluhutan Siregar. "Integrasi Ilmu-Ilmu Keislaman dalam Perspektif M. Amin Abdullah." Miqot: Jurnal Ilmu-Ilmu Keislaman (2014).

Saputera, Abdur Rahman Adi. "Analisis Faktor Penghambat Dan Pendukung Implementasi KTSP di Madrasah Aliyah Alkhairaat Kota Gorontalo." Kariman 07, No. Pendidikan dan Pemikiran Keislaman (2019).

Sugiyono. Pendekatan Kuantitatif, Kualitatif, Kombinasi, R\&D Dan Penelitian Evaluasi. Metodologi Penelitian. Purwokerto: Percetakan Alphabet, 2017.

Syamsi Pomalingo, Dkk. Sejarah Pendidikan di Gorontalo. Edited By Percetakan BNPB Sulawesi Utara. Manado, 2012.

Waston, Waston. "Pemikiran Epistemologi Amin Abdullah Dan Relevansinya Bagi Pendidikan Tinggi Di Indonesia." Profetika: Jurnal Studi Islam (2016). 